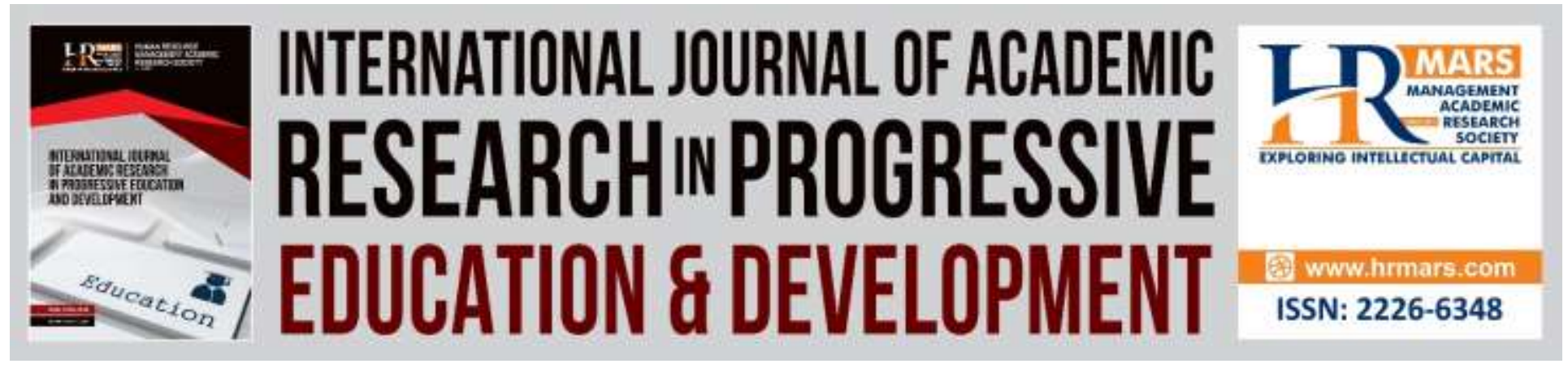

\title{
Well-Being and Perceived School Work of Upper Secondary Students High School: A Case Study of Togo
}

Bawa Ibn Habib

To Link this Article: http://dx.doi.org/10.6007/IJARPED/v9-i2/7173

DOI:10.6007/IJARPED/v9-i2/7173

Received: 27 February 2020, Revised: 23 March 2020, Accepted: 11 April 2020

Published Online: 30 April 2020

In-Text Citation: (Habib, 2020)

To Cite this Article: Habib, B. I. (2020). Well-Being and Perceived School Work of Upper Secondary Students High School: A Case Study of Togo. International Journal of Academic Research in Progressive Education and Development, 9(2), 1-13.

Copyright: (C) 2020 The Author(s)

Published by Human Resource Management Academic Research Society (www.hrmars.com)

This article is published under the Creative Commons Attribution (CC BY 4.0) license. Anyone may reproduce, distribute, translate and create derivative works of this article (for both commercial and non-commercial purposes), subject to full attribution to the original publication and authors. The full terms of this license may be seen at: http://creativecommons.org/licences/by/4.0/legalcode

Vol. 9(2) 2020, Pg. 1 - 13

http://hrmars.com/index.php/pages/detail/IJARPED JOURNAL HOMEPAGE

Full Terms \& Conditions of access and use can be found at http://hrmars.com/index.php/pages/detail/publication-ethics 


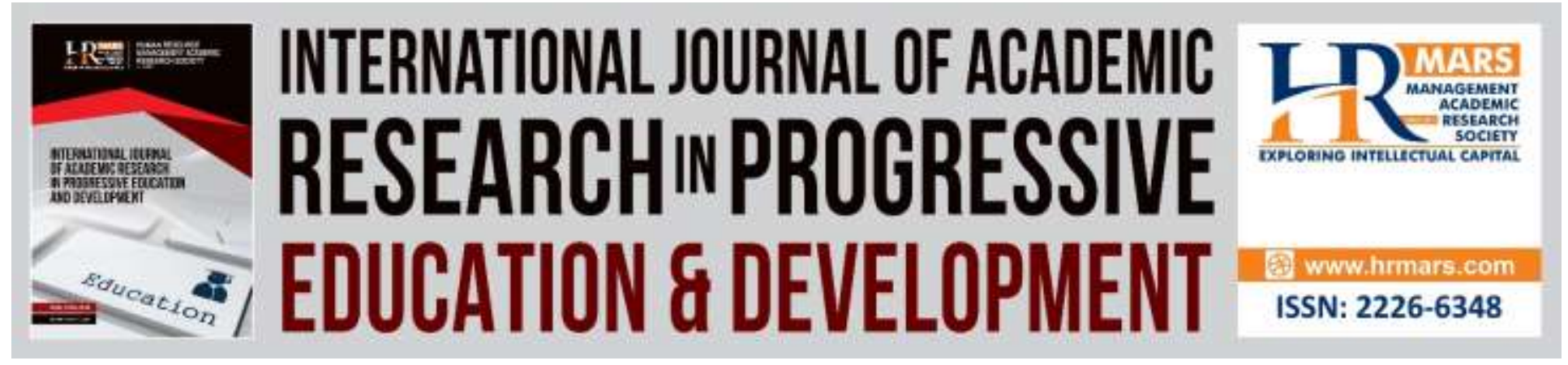

\title{
Well-Being and Perceived School Work of Upper Secondary Students High School: A Case Study of Togo
}

\author{
BAWA Ibn Habib \\ Department of Applied Psychology, University of Lome, Togo \\ Email: ihbawa@gmail.com
}

\begin{abstract}
This study aims to verify the relationship between well-being and the perceived schoolwork of upper secondary students in Lome, Togo. To achieve this objective, a sample of 644 students from the upper secondary was formed. Well-being was measured using the multidimensional scale of school well-being by Guimard et al. (2015). This scale was adapted to the context and its psychometric qualities controlled. A dichotomous question made it possible to inform the perceived school work. All the data collected was subjected to statistical processing with the calculation of the $Z$ test of Kolmogorov-Smirnov, $\alpha$ of Cronbach, factorial analyzes, the correlation $r$ of Pearson and analyzes of variance. The results obtained reflect the good psychometric qualities of the scale. There is no relationship between well-being and perceived schoolwork. However, the good pupils seem very satisfied in class, with their relationships with the peers and their relationship to the assessments
\end{abstract}

Keywords: Well-being, Perceived School Work, Psychometric Qualities, Students

\section{Introduction}

Togo's education system is plagued at the second cycle of secondary school with very high repetition rates. For example, nearly $22 \%$ of students in this cycle repeat their class, with the result of dropping out of school without obtaining the baccalaureate diploma (Directorate of Educational Planning and Assessment, 2019). To understand this state of affairs, the Togolese scientific literature is full of a series of studies $s$ whose set of identified factors can be grouped into three categories: sociological factors related to the family environment (Bawa et al. 2019) and the quality of parent-child interactions (Bawa, 2018), institutional factors (conditions of insufficient school supervision, overcrowding, etc.) and personal factors such as self-esteem (Bawa, 2011), perceptions of skills (Bawa \& Alfa, 2017). By understanding school well-being, we think we will fill the gap noted in the list of personal factors addressed in research in Togo. Ultimately, we plan to make proposals in order to "include in the assessment protocols of students a measure of their satisfaction or well-being at school " (Guimard et al. 2015, p. 164) ; 
which could " allow education professionals to better understand the behavior of young people and offer courses of action to improve their quality of life " (idem).

The importance of this study lies in the fact that it is a first in Togo. It fills the gap that exists in the Togolese literature on the relationship between well-being and perceived school work.

In the following lines, we will clarify the concept of well-being and then review the literature that relates this concept to the academic success of students. At the end, we will identify our research objectives and hypotheses.

\section{Conceptual frame}

The variety of terms used to know happiness, life satisfaction, the personal development, quality of life ... to designate welfare through literature makes it particularly difficult or blur the definition of this concept (Bacro et al., 2011; Coudronnière, 2015; Garcia-Bacete et al., 2014; Fenouillet, 2014; Florin \& Guimard, 2017; Upton et al., 2008).

Bacro et al. (2011) find four different conceptions of quality of life : the objective conception, which refers to material living conditions and the absence of physical illness; the subjective conception, which corresponds to the degree of satisfaction and / or overall happiness felt in life; the integrative conception, which considers the quality of life as having an objective and subjective component; and the dynamic integrative conception, which refers to the multidimensional evaluation, made by the individual, of the relationships he maintains with his environment in based on both objective and subjective criteria (Bruchon-Schweitzer, 2002; Lawton, 1997). The welfare refers then to design subjective quality of life (Bacro et al., 2017).

The SWB corresponds to "cognitive and emotional evaluation made by the child of his satisfaction in different areas of life, including with regard to experiences in the school context" (Bacro et al., 2017, p. 63). The hedonic conception associates well-being with pleasure, satisfaction, subjective happiness, the search for happiness being considered as the principle motivating human activity (Florin \& Guimard, 2017). According to Diener (1984), a positive feeling of subjective well-being consists of living a lot of positive affects, few unpleasant affects and feeling great general satisfaction with one's life. The World Health Organization (1996, p.384) defines quality of life as " the way people perceive their existence taking into account the culture and the value system in which they live and according to their goals. , their expectations, their standards and their concerns. This quality depends, of course, on physical health, psychological state, level of independence, social relationships, environmental factors and personal beliefs". The consensus that emerges from all of the authors is to recognize the multidimensional nature of this concept even if at present no consensus seems to be emerging concerning the fields or dimensions to be apprehended in order to assess it (Coudronnière et al., 2015; Matza et al., 2005).

Applied in the school context, Konu \& Rimpela (2002), Baker et al. (2003), Eccles \& Roeser (2011) and Guimard et al. (2014) propose models likely to help identify the dimensions that constitute the quality of life in school (Cnesco, 2017; Florin \& Guimard, 2017).

Konu \& Rimpela (2002) propose a sociological model of well-being which supposes that "well-being is defined as a state in which the individual can satisfy three basic needs: " having ", "loving " and " being ". "Having" refers to the material conditions of school life and includes the physical environment, the learning environment offered by the establishment, as well as the 
services to the students. "Loving" concerns interpersonal and social relationships and takes into account the social learning environment such as student-teacher relationships, relationships with peers and the educational community. "Being" is related to the personal growth needs of students which can be brought by devices promoting their participation in decision-making, taking initiatives, self-confidence. In addition to these three needs, there is the state of health (Health, relating to physical, psychological or somatic symptoms) considered to be an important element in the well-being of students at school" (Cnesco, 2017, p. 24). In sum, the concept of well-being includes school conditions, social relationships, means of personal fulfillment and health status (Konu \& Rimpela, 2002).

Baker et al. (2003) identify two sets of environmental variables likely to promote academic satisfaction: proximal variables such as academic capacity, gender, ethnicity, socio-economic status, mental health, family, and distal variables, less directly related to children, such as school climate, classroom practices, school organization and peer relationships. According to the authors, distal factors interact with proximal factors and have positive effects on students if they meet their development needs (Florin \& Guimard, 2017).

Eccles \& Roeser (2011 a and b), the school environment is designed as a system comprising seven levels capable of influencing the development and well-being of children and adolescents (Cnesco, 2017). Level 1 corresponds to the nature of the academic activities, i.e. the content of the curriculum and the conception of teaching to build knowledge and motivate students (how things are taught). Level 2 refers to the social structure of classroom learning activities (individual, small group or large group work; work in groups of levels; pedagogy aimed or not at competition). Level 3 characterizes the quality of pedagogy and the classroom climate and refers to different aspects: the professional identity of teachers, their beliefs in the effectiveness of their teaching practices, their expectations of students, their socio-emotional skills, the social and educational atmosphere they create in their class, their ability to manage the class (for example: does the teacher control or allow autonomy?). Level 4 corresponds to the implementation in the establishment of groups of academic levels and of a policy of curriculum differentiation (grouping of pupils within a class for different subjects; grouping of pupils of several classes with different teachers). Level 5 characterizes the organizational structure of the establishment and its culture: financial, material and human resources, the characteristics of the pupils received (depending on whether they come from disadvantaged families or not), the size of the school, the social, moral and academic culture, the physical environment of the establishment, the practices linked to the start and end of the courses as well as the annual school calendar. Level 6 describes the relationships between the school, families and the community (other local institutions / structures). Finally, level 7 corresponds to the educational policy implemented within the establishment in connection with the regional or national governance system (Eccles \& Roeser, 2011; cited by Florin \& Guimard, 2017).

Finally, Guimard et al. (2015) in the study on "the well-being of students in school and college. Validation of a multidimensional scale, descriptive and differential analyzes", identify six dimensions of well-being in school, namely Relation with teachers, satisfaction in school activities, satisfaction in class, satisfaction in peer relationships, feeling of security, satisfaction with assessments. This model has the advantage, apart from being in French but also having 
INTERNATIONAL JOURNAL OF ACADEMIC RESEARCH IN PROGRESSIVE EDUCATION AND

DEVELOPMENT

Vol. 9, No. 2, 2020, E-ISSN: $2226-6348$ @ 2020 HRMARS

taken into account the shortcomings of the previous models. For these reason's that we adopt in this study.

\section{Literature Review}

Several authors have tried to define in empirical studies the relationship between academic performance and well-being at school.

Indeed, the work of (Huebner \& Alderman, 1993; Ash \& Huebner, 1998; Huebner, 1991) provided by Bacro et al. (2017) carried out among schoolchildren and middle school students, conclude that overall life satisfaction is not linked to academic performance. In a college comparison with learning difficulties and all-comers, Mac McCullough \& Huebner (2003) show that these groups obtain similar scores on different dimensions of "Multidimensional Students 'Life Satisfaction Scale' (MSLSS), including that relating to academic satisfaction (Bacro et al., 2017). On the other hand, almost everywhere in the world, it is shown that the phenomenon of well-being has a relatively important impact on the behavior of the pupil in the school environment and on his results and his school performances (Hoy \& Hannum, 1997).

In Finland, Kirkcaldy et al. (2004), from the PISA database, find that student well-being is always linked to academic performance (in science, mathematics and reading). The well- being of students at school is even able to affect other characteristics that are important for academic success such as performance, motivation and attitude toward learning (Veenstra \& Kuyper, 2004). In Australia, Murray-Harvey (2010, in a study of adolescents aged 10-16 years find that student academic success is correlated with social relationships with family, peers and teachers, psychological health, felt towards the establishment school and sense of belonging. in Ireland North, Miller et al. (2013), in a study of 1081 amounted to 7 to 11 years, show that the well-being and academic performance a robust relationship independent of gender and precariousness. Students who feel good and happy at school, regardless of their living context, have better academic results than those with a low level of well-being. Germany Cred et al. (2015) found that academic achievement scores and life satisfaction are correlated. This association is moderated by maternal education (National Council of evaluation of education systems, 2019). In the end, in France, Fenouillet et al. (2014) and Guimard et al. (2015) arrive at the same results. Indeed, Fenouillet et al. (2014), cited by Bacro et al. (2017) reported correlations positive and significant between school satisfaction, results in $\mathrm{x}$ continuous assessment and final examinations s patent colleges and Guimard et al. (2015) find that several dimensions of their multidimensional school well-being questionnaire (satisfaction with relationships with teachers, school activities and assessments) are positively associated with the academic performance of schoolchildren and / or middle school students. Bacro et al. (2017) also confirm the existence of relationships between academic performance and well-being.

In view of the above, even if the results that each other reached about the relationship between well-being and academic performance throughout the world are mixed (Bacro et al., 2017), they have at least deserves to exist. In Togo, to our knowledge, the scientific literature is characterized by a notorious lack of studies on this subject. 
Vol. 9, No. 2, 2020, E-ISSN: 2226-6348@ 2020 HRMARS

\section{Aim and Hypothesis of the Study}

Aim of this study is to verify whether there is a relationship between the well-being and the perceived schoolwork of upper secondary students. With that, we postulate that the good students are those who feel good in their school. The same is true in all dimensions of school well-being.

Following this section, we describe the methodological framework put in place to verify this hypothesis.

\section{Method}

\section{Population and Sample}

The Togolese education system includes three levels of schooling: the primary level, the secondary level and the university level. The secondary level is made up of two cycles: the first cycle of the secondary or the college and the second cycle of the secondary or the high school. It is precisely the students of this last cycle that constitutes our study population. These are students from nine high schools in the city of Lomé who participated in the survey. They were recruited using the "all comers "technique. In total, there are 644 (average age = 19 years) composed of $59.3 \%$ boys against $40.4 \%$ girls. Next, $56.7 \%$ of students in the Scientific D series; $41.8 \%$ of students in the Literary series $A$ and $1.6 \%$ of students in the Scientific series C. Compared to the level of education of their father, the head of the family, the pupils whose the father has the levels "Lycée" (37.30) and "university" (23.30) are more numerous than the others. We note a relative missing data of this information.

\section{Data Collection Instruments}

Two instruments were used to collect data. Each of these instruments is intended to measure a specific variable.

\section{Independent Variable: School Well-being}

This variable was measured using the Multidimensional Well-being Scale of Guimard et al. (2015). It is a scale constructed and validated in the French context. It is made up of 30 items whose objective is "to understand the different aspects of school life contributing not only to the level of student satisfaction, but also to their integration into the peer group and the absence of affect negative that can be felt at school "(Guimard et al., 2015, p. 167 ).

For each item, two categories of students are presented to the child, generally distinguished by a simple negation ("Some students are afraid of ..." against "Other students are not afraid of ..."). The student must choose the one that most closely resembles him. He is then asked to clarify his answer by indicating whether the category of students he has chosen is really or more or less like him. The answers are distributed on a Likert scale in 4 points, a score of 4 always corresponding to the best appreciation. The dimensions evaluated are 6 in number: relationships with teachers, school activities, satisfaction with the class, relationships with peers, feeling of security and relationship to assessments.

Since this scale is borrowed, we wanted to check its metrological qualities following its contextual adaptation. The results are presented in section 4.1. Exploratory analyzes. 
Vol. 9, No. 2, 2020, E-ISSN: 2226-6348@ 2020 HRMARS

\section{Dependent Variable: Perceived School Work}

It is represented by the perceived school work. It is about the pupil's perception of his own school work. To find out, he had to answer the following question: "Overall, how do you find your school work?" The answer is dichotomous: good work and bad work. The student chooses "good job" when he considers that his academic results are generally good; otherwise he chooses "bad job".

\section{Data Analyses}

The distribution is checked using the degree of asymmetry and flattening of the data, the mean and the standard deviation. Alpha Cronbach and the matrix of correlations inter-scale is $t$ used to ensure the respective reliability of our measuring instrument. We carried out a factorial analysis in principal components with rotation "varimax" to define the factorial structure. Finally, Pearson's correlation matrix $r$ allowed us to see the relationship between well-being and perceived educational status.

\section{Findings}

\section{Exploratory Analyzes}

\section{Descriptive Statistics}

Table 2: Mean, standard deviation, asymmetry and flattening of the distribution $(\mathrm{N}=644)$

\begin{tabular}{|c|c|c|c|c|}
\hline Ladders & Average & $\begin{array}{l}\text { Standard } \\
\text { deviation }\end{array}$ & Asymmetry & flattening \\
\hline $\begin{array}{l}\text { Relationship with } \\
\text { Teachers }\end{array}$ & 13.72 & 2.49 & -0.17 & 0.46 \\
\hline $\begin{array}{l}\text { Satisfaction / } \\
\text { school activities }\end{array}$ & 13.95 & 2.27 & 0.23 & 0.32 \\
\hline $\begin{array}{l}\text { Satisfaction / } \\
\text { Class }\end{array}$ & 13,03 & 2.48 & 0.07 & -0.17 \\
\hline $\begin{array}{l}\text { Satisfaction / } \\
\text { joint relationship }\end{array}$ & 12.38 & 2.27 & 0.17 & 0.65 \\
\hline $\begin{array}{l}\text { Feeling } \\
\text { Security }\end{array}$ & 11.57 & 3.20 & 0.18 & -0.11 \\
\hline $\begin{array}{l}\text { Satisfaction / } \\
\text { assessments }\end{array}$ & 14.14 & 2.79 & -0.29 & 0.18 \\
\hline $\begin{array}{l}\text { School } \\
\text { well-being }\end{array}$ & 78.79 & 8.69 & 0.16 & 2.00 \\
\hline
\end{tabular}

As can be seen in the table above, the means indicate that there is no capping effect (value of 4), nor floor effect (value of 1). The asymmetry and flattening indices are acceptable since they are close to 0 and do not exceed [-2 and 2] (Bentler, 1983). 
INTERNATIONAL JOURNAL OF ACADEMIC RESEARCH IN PROGRESSIVE EDUCATION AND DEVELOPMENT

Vol. 9, No. 2, 2020, E-ISSN: 2226-6348 @ 2020 HRMARS

\section{Internal Consistency}

Table 2: Mean, standard deviation, asymmetry and flattening of the distribution

\begin{tabular}{lll}
\hline Ladders & $\begin{array}{l}\text { Alpha of } \\
\text { Cronbach }\end{array}$ & $\begin{array}{l}\text { Number of } \\
\text { items }\end{array}$ \\
\hline $\begin{array}{l}\text { Relationship with } \\
\text { teachers }\end{array}$ & 0.63 & 5 \\
$\begin{array}{l}\text { Satisfaction / } \\
\text { school activities }\end{array}$ & 0.74 & 5 \\
$\begin{array}{l}\text { Satisfaction / } \\
\text { class }\end{array}$ & 0.70 & 5 \\
$\begin{array}{l}\text { Satisfaction / } \\
\text { joint relationship }\end{array}$ & 0.60 & 5 \\
$\begin{array}{l}\text { Feeling } \\
\text { security }\end{array}$ & 0.69 & 5 \\
$\begin{array}{l}\text { Satisfaction / } \\
\text { assessments }\end{array}$ & 0.67 & 5 \\
$\begin{array}{l}\text { School } \\
\text { well-being }\end{array}$ & 0.82 & 30 \\
\hline
\end{tabular}

The internal coherence coefficients for all the subscales vary between 0.60 and 0.74 . Cronbach's alpha of the global scale is 0.82 . All these values are satisfactory and prove that all of the items on the scale have good internal consistency.

\section{Correlation Matrix between Scales}

Table 3: Matrix of correlations between the different scales

\begin{tabular}{|c|c|c|c|c|c|c|c|}
\hline Ladders & 1 & 2 & 3 & 4 & 5 & 6 & 7 \\
\hline $\begin{array}{l}\text { 1- School } \\
\text { well-being }\end{array}$ & 1 & & & & & & \\
\hline $\begin{array}{l}\text { 2-Relationship } \\
\text { with teachers }\end{array}$ & $0.54 * *$ & 1 & & & & & \\
\hline $\begin{array}{l}\text { 3- Satisfaction / } \\
\text { school activities }\end{array}$ & $0.54 * *$ & $0.15 * *$ & 1 & & & & \\
\hline $\begin{array}{l}\text { 4- Satisfaction / } \\
\text { class }\end{array}$ & $0.56 * *$ & $0.23 * *$ & $0.17 * *$ & 1 & & & \\
\hline $\begin{array}{l}\text { 5- Satisfaction / } \\
\text { joint relationship }\end{array}$ & $0.52 * *$ & $0.21 * *$ & $0.24 * *$ & $0.29 * *$ & 1 & & \\
\hline $\begin{array}{l}\text { 6- Feeling of } \\
\text { security }\end{array}$ & $0.63 * *$ & $0.17 * *$ & $0.21 * *$ & $0.12 * *$ & $0.11 * *$ & 1 & \\
\hline $\begin{array}{l}7 \text { Satisfaction / } \\
\text { assessments }\end{array}$ & $0.55 * *$ & $0.10 *$ & $0.15 * *$ & $0.13 * *$ & 0.05 & $0.30 * *$ & 1 \\
\hline
\end{tabular}

* Significance at threshold .05; ${ }^{* *}$ Significance at the threshold .01

The table above presents the correlation matrix between the School Well-being scale and its six subscales. In general, we observe that the School Well-being scale is positively correlated with 
Vol. 9, No. 2, 2020, E-ISSN: 2226-6348@ 2020 HRMARS

all the subscales with Pearson $r$ coefficients ranging from 0.52 to 0.63 . Likewise, all the subscales correlate positively with each other except the relationship between "Satisfaction / parity relationship" and "Satisfaction / evaluations."

\section{Factorial Structure}

The estimate of the Kaiser-Meyer-Olkin coefficient (KMO) is 0.71. Bertlett's Sphericity test (approximate chi-square $=2284.79$; dof $=435$ ) is significant at the threshold $p<.00001$. These respective values prove that the correlations between the different items that make up our scale are good for carrying out factor analysis in principal components with "varimax" rotation. This analysis shows nine factors with a characteristic root greater than 1 . These nine factors identified explain $49.95 \%$ of the variance. However, we observe that not only item 3 "I don't like my class too much " saturates for more than one factor but also there is a low number of items for certain factors. In a second analysis, this time by fixing the number of factors at 6 , in accordance with the theoretical basis (Bacro et al., 2014), we obtained a clear factor structure with saturations all greater than 0.4. In addition, no item saturates on more than one factor. The 6 new factors identified explain $38.62 \%$ of the variance.

\section{Relationship between well-being and Perceived School Work}

Table 4: ANOVA: Well-being and perceived school work $(\mathrm{N}=644)$

\begin{tabular}{|c|c|c|c|c|c|}
\hline $\begin{array}{l}\text { School well-being and its } \\
\text { dimensions }\end{array}$ & $\begin{array}{l}\text { Overall, how do you } \\
\text { find your school } \\
\text { work? }\end{array}$ & $\mathrm{N}$ & Mean & sd & $\begin{array}{l}\text { Student's } \\
\mathrm{t}\end{array}$ \\
\hline \multirow{2}{*}{$\begin{array}{l}\text { School } \\
\text { well-being }\end{array}$} & Well & 517 & 79.05 & 8.48 & \multirow[t]{2}{*}{$1.54 \mathrm{~ns}$} \\
\hline & Bad & 127 & 77.73 & 9.43 & \\
\hline \multirow{2}{*}{$\begin{array}{l}\text { Relationship } \\
\text { teachers }\end{array}$} & Well & 517 & 13.81 & 2.42 & \multirow[t]{2}{*}{$1.84 \mathrm{~ns}$} \\
\hline & Bad & 127 & 13.35 & 2.73 & \\
\hline \multirow{2}{*}{$\begin{array}{l}\text { Satisfaction with school } \\
\text { activities }\end{array}$} & Well & 517 & 13.93 & 2.21 & \multirow[t]{2}{*}{-0.49 ns } \\
\hline & Bad & 127 & 14.04 & 2.49 & \\
\hline \multirow{2}{*}{$\begin{array}{l}\text { Class } \\
\text { satisfaction }\end{array}$} & Well & 517 & 13.18 & 2.40 & \multirow[t]{2}{*}{$3.03 \mathrm{~s}$} \\
\hline & Bad & 127 & 12.44 & 2.70 & \\
\hline \multirow{2}{*}{$\begin{array}{l}\text { Satisfaction } \\
\text { relationship }\end{array}$} & Well & 517 & 12,51 & 2.23 & \multirow[t]{2}{*}{$2.91 \mathrm{~s}$} \\
\hline & Bad & 127 & 11.86 & 2.35 & \\
\hline \multirow{2}{*}{$\begin{array}{l}\text { Security } \\
\text { feeling }\end{array}$} & Well & 517 & 11,60 & 3.15 & \multirow[t]{2}{*}{$0.56 \mathrm{~ns}$} \\
\hline & Bad & 127 & 11.43 & 3.42 & \\
\hline \multirow{2}{*}{$\begin{array}{l}\text { Satisfaction } \\
\text { assessments }\end{array}$} & Well & 517 & 14,02 & 2.69 & \multirow[t]{2}{*}{$-2.17 \mathrm{~s}$} \\
\hline & Bad & 127 & 14.62 & 3.12 & \\
\hline
\end{tabular}

According to Table 4, there is no relation between Well-being and perceived school work (Student's $t=1.54$ is not significant). On the other hand, when we look among the School wellbeing subscales, there is a significant relationship between the "Satisfaction / class", "Satisfaction / gender relationship", "Satisfaction / assessments" subscales and school work perceived. 


\section{Discussion}

The objective of this study was to check whether there is a relationship between the wellbeing and the perceived schoolwork of upper secondary students in Lomé in Togo. In this goal, we have postulated that good students are those who feel good about their school, this in all dimensions of wellness education. A sample of students in the 12th grade participated in the survey. First, and on this sample, the metrological qualities of the instrument for measuring school well-being, borrowed from the French context, were checked. It appears that this instrument has all acceptable qualities. In a second step, the results in relation to our hypothesis invalidate the latter. In other words, there is no relation between school well-being and school work perceived in the Togolese context. This observation also agrees with the international results of other authors (Ash \& Huebner, 1998; Huebner, 1991; Huebner \& Alderman, 1993; Mac Cullough \& Huebner, 2003). These authors conclude that overall life satisfaction is not linked to academic performance. On the other hand, in other countries, it is well and truly shown that school well-being and school performance are closely linked (Cred et al., 2015; Fenouillet et al., 2014; Guimard et al., 2015; Kirkcaldy et al., 2004; Miller et al., 2013; Veenstra \& Kuyper, 2004) . It must be recognized, first, that the divergence of our result with that of others could be understood by the fact that these studies focused on primary and middle school while ours on high school. Then, this result that we found does not surprise us at all since in the public high schools of Lome where the survey took place, the working conditions of the students leave something to be desired. It's characterized by overstaffing (too many students and / or a lack of supervisory staff), a very inauspicious school built to learning because of poor thermal insulation and / or sound of causing an noise and heat, poor lighting in classrooms (Hébert \& Dugas, 2017). It is shown that a good school building provides students with comfort, aesthetics and the satisfaction of teaching and learning needs that affect school well-being (Barrett \& et al., 2015; Cnesco, 2017). The school climate in terms of student safety is also unfavorable because it is marked by corporal punishment on the part of the supervisory team despite their prohibition by the children's code of Togo in its Article 376: "Corporal punishment and any other form of violence or ill-treatment are prohibited in schools and vocational training establishments ". In clear, for years the terms described, students can only present a malaise evident vitiating their schoolwork. Finally, it is possible that the cultural characteristics explain the differences observed (Bacro et al., 2014).

But when doing a specific analysis of our results, it appears that even if the overall well-being

is not associated with perceived schoolwork, certain sub-dimensions are, in this case the satisfaction in class, the satisfaction in the relationship between peers and satisfaction with assessments. At Guimard et al. (2015) , it is rather satisfaction with relationships with teachers, school activities and assessments that are positively associated with the academic performance of schoolchildren and / or college students, after controlling for various socio-demographic and school variables (age, sex, type establishment, previous school career, etc.). The sub-dimension "satisfaction with the evaluations" is common to both contexts. In class as well as with friends, students in the final year classes work together in the expectation of passing the baccalaureate exam. Very often, this collaboration is done in small working groups. Lowest in a material are helped by strongers. Compared to assessments, since the final year class is an exam class, 
teachers, without complacency, assess students objectively and in accordance with good practice, which contributes to their well-being.

\section{Conclusion}

As part of this study, we postulated that good students are those who feel good in their school, this in all dimensions of school well-being. To test this hypothesis, a methodological framework comprising 644 students in the 12th grade and a measurement instrument borrowed from the French context was put in place. The data were processed using analysis of variances. The results obtained, like some previous work, do not confirm a link between school well-being and perceived school work. However, the sub-dimensions "classroom satisfaction", "satisfaction in the relationship with peers" and "satisfaction with the assessments" seem to be well observed among students who have a good perception of their school work.

It goes without saying that in the college where our survey was carried out, the students experienced a malaise which seemed to be linked to overcrowding, the bad school climate and even the poor working and learning conditions linked to the inadequate school building. This fact leads us to invite the public authorities in charge of the Togolese school to put the necessary means to improve working and learning conditions and the school climate in order to boost the well-being of students.

A major limitation prevents any generalization of the results of this study. This is the use of an instrument for measuring school well-being in a context different from that of Togo. In the next studies, we could set out to build an instrument from indicators drawn locally.

\section{References}

Ash, C., \& Huebner, E. S. (1998). Life satisfaction reports of gifted middle-school children. School Psychology Quarterly, 13, 310-321.

Bacro, F., Ferriere, S., Florin, A., Guimard, P., \& Ngo, H. (2014). Student well-being in school and college: validation of a multidimensional assessment scale and differential analyzes. Terminal research report, Convention No. 2013-013 with the MEN (DEPP), the Defender of Rights (DD) and the National Agency for Social Cohesion and Equal Opportunities (Acsé).

Bacro, F., Rambaud, A., Florin, A., \& Guimard, P. (2011). The evaluation of the quality of life of children aged 3 to 6 and its usefulness in the field of education. ANAE, 112, 1-6.

Barrett, P., Davies, F., Zhang, Y., \& Barett, L. (2015). The impact of classroom design on pupils' learning: Final results of a holistic, multi-level analysis. Building and Environment, 89, 118-133.

Bentler, P. M. (1983). Some contributions to efficient statistics in structural models: Specification and estimation of moment structure. Psychometrica, 48, 493-517.

Bruchon-Schweitzer, M. (2002). Health psychology. Models, concepts and methods. Paris: Dunod

Cnesco. (2017). Does the French school offer a living environment favorable to the learning and well-being of the students? Summary file available onhttps://www.cnesco.fr/fr/qualitevie-ecole/

National Education Systems Assessment Council. (2019). Quality of life and academic performance. Available at https://www.cnesco.fr/fr/publications/ 
Coudronnière, C., Bacro, F., Guimard, P., \& Florin, A. (2015). What concept of quality of life and well-being in children aged 5 to 11 ? Childhood, 2, 225-243.

Crede, J., Wirthwein, N., Elvany, Mc., \& Steinmayr, R. (2015). Adolescents 'academic achievement and life satisfaction: the role of parents' education. Frontiers in psychology, 6(52), 1-8.

Diener, E. (1984). Subjective well-being. Psychological Bulletin, 95, 542-575.

Education Planning and Assessment Directorate. (2019). National yearbook of school statistics 2018-2019, 54 ${ }^{\text {th }}$ year. Lome: Ministry of Primary and Secondary Education.

Eccles, J.S., \& Roeser, R. W. (2011a). Schools as developmental contexts during adolescence. Journal of Research on Adolescence, 21, 225-241.

Eccles, J. S., \& Roeser, R.W. (2011b). School and community influences on human development. In $\mathrm{MH}$ Borstein \& ME Lamb. Developmental Science: an Advanced Textbook, NY: Psychology Press. pp. 571- 642.

Bacro, F., Guimard, P., Florin, A., Ferrière, S., \& Gaudonville, T. (2017). Perceived well-being, academic performance and quality of life of children in school and college: longitudinal study. Childhood, 1, 61-80.

Fenouillet, F., Heutte, J., Martin-Krumm, C., \& Boniwell, I. (2014). French validation of the multidimensional life satisfaction scale for students. Canadian Journal of Behavioral Science, 47(1), 1 - 29.

Garcia-Bacete, F. J., Perrin, M. G., Schneider, B. H., \& Blanchard, C. (2014). Effects of schools on Well-being of children and Adolescents. In A. Ben-Arieh, F. Casas, I. Frones \& J.E. Corbien (eds). Handbook of Child Well-being. Theories, methods and policies in Global perspectives. Springer, Dordrecht, Heidelberg, New York, London.

Guimard, P., Bacro, F., Ferrière, S., Florin, A., \& Gaudonville, T. (2015). Student well-being in school and college. Validation of a multidimensional scale, descriptive and differential analyzes. Education and Training, 88-89, 163-184.

Hébert, T., \& Dugas, É. (2017). What school spaces for relational well-being? Survey on the feelings of French college students. Education and socialization, 43, [Online]: URL: http://journals.openedition.org/edso/1904; DOI: 10.4000 / edso.1904. (accessed December 04, 2019).

Hoy, W. K., \& Hannum, J. W. (1997). Middle School Climate: An Empirical Assessment of Organizational Health and Student Achievement. Educational Administration Quarterly, 33, 290-311. http://dx.doi.org/10.1177/0013161X97033003003.

Huebner, E. S. (1991). Correlates of life satisfaction in children. School Psychology Quarterly, 6, 103-111. doi: 10.1037 / h0088805.

Huebner, E. S., \& Alderman, G. L. (1993). Convergent and discriminant validation of a children's life satisfaction scale: its relationship to self- and teacher-reported psychological problems and school functioning. Social Indicators Research, 30, 71-82.

Kirkcaldy, B., Furnham, A., \& Siefen, G. (2004). The relationship between health efficacy, educational attainment, and well-being among 30 nations. European Psychologist, 2(9), 107-119.

Konu, A., \& Rimpela, M. (2002). Well-being in schools: a conceptual model. Health Promotion International, 17(1), 79-87. 
Lawton, M. P. (1997). Assessing quality of life in Alzheimer disease research, Alzheimer disease and associated disorders, 11, 91-99.

Matza, L. S., Swensen, A. R., Flood, E. M., Secnik, K., \& Leidy, N. K. (2004). Assessment of healthrelated quality of life in children: A review of conceptual, methodological, and regulatory issues. Value Health, 7(1), 79-92.

McCullough, G., \& Huebner, E. S. (2003). Life Satisfaction Reports of Adolescents with Learning Disabilities and Normally Achieving Adolescents Journal of Psychoeducational Assessment, 21(4), 311-324. DOI: 10.1177 / 073428290302100401.

Miller, S., Connolly, P., \& Maguire, L. (2013). Wellbeing, academic buoyancy and educational achievement in primary school students. International Journal of Educational Research, 62, 239-248.

Murray-Harvey, R. (2010). Relationship influences on students' academic achievement, psychological health and well-being at school. Educational and Child Psychology, 1(27), 104-115.

World Health Organization. (1996). What quality of life? World Health Forum, 17, 384-386.

Upton, P., Lawford, J., \& Eiser, C. (2008). Parent-child agreement across child health-related quality of life instruments: a review of the literature. Quality of Life Research, 17, 895913.

Veenstra, R., \& Kuyper, H. (2004). Effective Students and Families: The Importance of Individual Characteristics for Achievement in High School. Educational Research and Evaluation, 10(1), 41-70. https://doi.org/10.1076/edre.10.1.41.26302 . 